\title{
PENGUATAN GERAKAN PENGELOLAAN SAMPAH KERING MELALUI SPIRIT SHODAQOH SAMPAH BAGI MASYARAKAT PEDUKUHAN SEMBUNG DAN KEMBANG, KABUPATEN SLEMAN
}

\section{STRENGTHENING THE DRY WASTE MANAGEMENT MOVEMENT THROUGH THE SPIRIT OF SHODAQOH FOR SEMBUNG AND KEMBANG COMMUNITIES IN SLEMAN DISTRICT}

\author{
Arie Kusuma Paksi ${ }^{1 *}$, Nanik Prasetyoningsih ${ }^{2)}$ \\ ${ }^{1)}$ Prodi Hubungan Internasional, Universitas Muhammadiyah Yogyakarta, Indonesia \\ email: ariekusumapaksi@umy.ac.id \\ ${ }^{2)}$ Prodi Magister Ilmu Hukum, Universitas Muhammadiyah Yogyakarta, Indonesia \\ email: nprasetyoningsih@gmail.com
}

\begin{abstract}
ABSTRAK
Program pengabdian ini bertujuan untuk menguatkan gerakan pengelolaan sampah di Pedukuhan Sembung dan Kembang, Kabupaten Sleman. Apalagi berdasarkan hasil penelitian awal terdapat 10 persen program bank sampah yang tidak aktif. Melalui serangkaian kegiatan pengabdian, yang melibatkan penyuluhan, workshop, kunjungan lapangan dan monitoring, dan fokus pada pengenalan dan penguatan prinsip shadaqoh demi tujuan sosial keagamaan dalam pengelolaan sampah, berpengaruh terhadap tingkat pengetahuan dan motivasi para pengelola bank sampah di Pedukuhan Sembung dan Kembang. Hal ini berarti program pengeloaan sampah perlu menekankan spirit tujuan sosial keagaamaan sehingga mendapat dukungan dari banyak pihak terutama warga sekitar.
\end{abstract}

Kata kunci: Penguatan, Pengelolaan, Sampah kering, Kesehatan lingkungan, Pemanasan global

\section{ABSTRACT}

This community service program aims to strengthen the waste management movement in Sembung and Kembang Villages at Sleman Regency. Moreover, based on the results of initial research, 10 percent of the waste bank program is inactive. Through a series of community service activities, which involve counseling, workshops, field visits and monitoring, and focus on introducing and strengthening the principles of shadaqoh for the sake of socio-religious goals in waste management, influencing the level of knowledge and motivation of the waste bank managers in Sembung and Kembang Villages. local people. This means that the future waste management program needs to emphasize the spirit of social and religious goals so that it gets support from many parties, especially the local communities.

Keywords: Strengthen, Management, Dry waste, Environmental health, Global warming

\section{PENDAHULUAN}

Sleman merupakan salah satu kabupaten

di Provinsi Daerah Istimewa Yogyakarta dengan jumlah penduduk sebesar 1.167.481 jiwa dan luas wilayah $574,82 \mathrm{~km}^{2}$. Sehingga jika dihitung maka tingkat kepadatan penduduk sebesar 2.031 jiwa/ $\mathrm{km}^{2}$ [1]. Adapun tingkat kepadatan penduduk tersebut berpengaruh terhadap timbunan sampah.
Misalnya, tercatat timbunan sampah di Kabupaten Sleman sebesar $2.335 \mathrm{~m}^{3} /$ hari atau setara dengan 2 liter/orang/hari. Sementara tingkat pelayanan pengangkutan sampah hanya sebesar 35,8 persen [2]. Seiring dengan pertambahan jumlah penduduk dan peningkatan aktifitas rumah tangga, jumlah sampah akan meningkat. Hal ini menuntut pemerintah setempat untuk 
menciptakan inovasi kegiatan pengelolaan sampah hasil aktifitas rumah tangga masyarakat.

Sampai saat ini Pemerintah Kabupaten Sleman cukup aktif dalam menyelenggarakan kegiatan sosialisasi, pelatihan dan pendampingan pengelolaan sampah dan ini diselenggarakan secara berkala [3]. Kegiatan tersebut disambut positif oleh masyarakat apalagi selain mengajarkan tentang nilai-nilai lingkungan, kegiatan yang sosialisasi dan pendampingan pengelolaan sampah oleh pemerintah setempat juga menekankan faktor ekonomis yang dapat diperoleh oleh masyarakat dari pengelolaan sampah [4].

Salah satu contoh gerakan pengelolaan sampah yang sedang berkembang pesat dan diadopsi menjadi program nasional sejak tahun 2012 (dan disahkan melalui Peraturan Menteri Lingkungan Hidup No. 13/2012) [5] adalah program bank sampah. Adapun cara kerja program bank sampah hampir mirip dengan bank-bank tempat penyimpanan uang. Masyarakat mengumpulkan sampah kering hasil aktivitas rumah tangga dan menyetorkannya ke bank. Kemudian petugas bank sampah akan mencatat dibuku rekening masing-masing rumah tangga - dalam hal ini disebut tabungan sampah - dan masyarakat mendapat keuntungan berupa uang tabungan.Adapun menurut informasi dari Dinas Lingkungan Hidup Kabupaten Sleman, hingga tahun 2018 terdapat 178 bank sampah yang telah dibangun masyarakat dan aktivitasnya tersebar di 76 desa [6].
Meskipun program pengelolaan sampah melalui bank sampah banyak dipuji dan jumlahnya meningkat dari tahun ke tahun, akan tetapi fakta dilapangan menunjukkan bahwa tidak semua gerakan bank sampah yang dikelola oleh masyarakat dapat berjalan secara simultan. Di Propinsi Jawa Barat, dari sekitar 2000 bank sampah, terdapat kurang lebih 400 yang tidak aktif [7]. Masalah yang sama juga terjadi disemua kabupaten dalam wilayah Propinsi Daerah Istimewa Yogyakarta. Di Kota Yogyakarta contohnya, dari sekitar 400 gerakan bank sampah, terdapat 70 bank sampah yang tidak aktif [8].

Di Kabupaten Sleman Sendiri, dari sekitar 200 bank sampah, hanya ada 178 unit bank sampah yang aktif [6]. Situasi ini menunjukkan perlunya kegiatan pengabdian yang mampu untuk mengidentifikasi masalah dan sekaligus mengadakan kegiatan yang bertujuan untuk menguatkan gerakan bank sampah di masyarakat sehingga aktivitasnya dapat berjalan dengan baik dan berkelanjutan demi menjaga kelestarian lingkungan [9].

Demi fokus dantercapainya target kegiatan, program pengabdian dilaksanakan di dua kecamatan di Sleman, yaitu di Dukuh Sembung, Purwobinangun, Pakem dan di Dukuh Becici, Dukuh Kembang dan Dukuh Dadapan di Desa Wonokerto, Kecamatan Turi. Adapun empat dukuh ini dijadikan lokasi pengabdian karenapemahaman masyarakat mengenai pentingnya menjaga lingkungan masih terbatas dan perlu ditingkatkan. Sehingga solusi yang 
ditawarkan adalah peningkatan kesadaran masyarakat untuk ikut serta dalam mengelola sampah demi menjaga lingkungan. Kedua, kesadaran masyarakat dalam mengelola sampah rumah tangga sudah ada namun terbatas sehingga motivasi dan sosialisasi mengenai pentingnya peran masing-masing rumah tangga dalam menjaga lingkungan masih perlu ditingkatkan. Dan terakhir, yang ketiga, meskipun telah ada program bank sampah akan tetapi belum berjalan dengan optimal dan bahkan tidak aktif. Sehingga perlu penguatan dan pendampingan supaya program tersebut dapat berjalan dengan baik. Akan tetapi, meskipun sejak awal Tim Pengabdi telah melibatkan empat pedukuhan, hanya 2 pedukuhan yang terlibat aktif mengikuti seluruh rangkaian program pengabdian.

\section{METODE PELAKSANAAN}

Demi mencapai target program dan berdampak berkesinambungan, ada tiga metode yang dilakukan dalam kegiatan pengabdian ini:

\section{Penyuluhan dan Workshop}

Penyuluhan dilakukan dalam upaya memperkuat pengetahuan para pengelola bank sampah melalui proses belajar bersama yang partisipatif. Selama kegiatan penyuluhan diberikan materi tentang arti penting mengelola sampah demi menjaga lingkungan dan langkah-langkah apa saja yang bisa dilakukan masyarakat guna menjaga lingkungan, salah satunya dengan mengelola sampah melalui bank sampah, dan apa saja barang-barang yang bernilai ekonomis. Kemudian, setelah pengetahuan para peserta program pengabdian meningkat, Tim Pengabdi selanjutnya melakukan kegiatan workshop yang secara khusus ditujukan untuk melatih para peserta bagaimana cara mengelola sampah kering dan apa saja manfaatnya.

\section{Field Trip}

Dalam metode field trip, peserta dibawa langsung untuk mengunjungi markas Gerakan Shadaqoh Sampah yang berlokasi di Kampung Brajan, Tamantirto, Bantul. Hal ini dimaksudkan agar peserta dapat mengamati dan mengalami langsung dan memperoleh informasi bagaimana praktek pengolahan sampah melalui spirit shadaqoh sehingga akan lebih bersemangat dalam mengembangkan program yang sudah dimiliki.

\section{Monitoring dan Evaluasi}

Dalam kegiatan pengabdian ini kegiatan monitoring dan evaluasi ini dilakukan setelah pelaksanaan penyuluhan, workshop dan field trip.Hal ini dilakukan untuk mengetahui dan mendapat masukan apa saja pencapaian program dan apa saja yang perlu ditingkatkan pada kegiatan pengabdian selanjutnya.

\section{HASIL DAN PEMBAHASAN}

Dengan menggunakan tiga metode yang telah dijelaskan di atas, secara rinci dapat disampaikan mengenai pelaksanaan kegiatan sebagai berikut. 
1. Pelaksanaan penyuluhan, workshop dan kunjungan lapangan (field trip)

pengelolaan sampah

Program Penyuluhan dan Workshop pemilahan Sampah Kering dilaksanakan pada tanggal 19 Januari 2020 di Aula Aula Gedung Pertemuan Pedukuhan Kembang dengan mengundang tujuh pengelola bank sampah dilingkungan Desa Purwobinangun dan Wonokerto. Namun yang dapat hadir hanya empat kelompok yaitu dari Pedukuhan Sembung,Becici, Kembang dan Dadapan, sementara tiga pedukuhan lainnya seperti Pulesari, Pojok, Manggungsari tidak dapat hadir meskipun telah diundang sejak jauh hari.

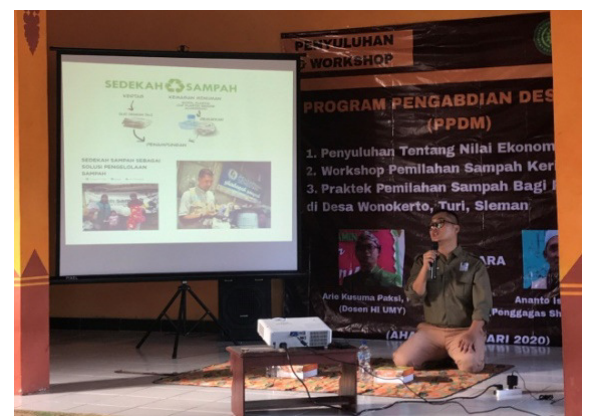

Gambar 1: Penyuluhan dan Workshop

Pemilahan Sampah Kering

Aula gedung pertemuan Pedukuhan Kembang, 19 Januari 2020

Acara dimulai dengan kegiatan penyuluhan tentang nilai ekonomi sampah kepada para peserta yang hadir yang disampaikan oleh Arie Paksi selaku Ketua Tim Pengabdi dari Universitas Muhammadiyah Yogyakarta

(UMY)

(Gambar 1). Meskipun para peserta yang hadir adalah mereka yang sudah menjalankan program pengelolaan sampah, akan tetapi informasi seperti aturan pemerintah melalui
Peraturan Menteri Lingkungan Hidup Nomor 13 tahun 2012 [5] tentang program 3R yaitu penggunaan kembali (reuse), pengurangan (reduce) and daur ulang (ryclecle) kembali ditekankan selama penyampaian materi. Adapun implementasi dari peraturan tersebut, pada prakteknya di Indonesia, berupa program bank sampah (yang paling dominan dipraktekkan dimasyarakat). Sementara model kegiatan pengelolaan sampah melalui shadaqoh sampah telah muncul walaupun jumlahnya sangat terbatas.

Kedua program tersebut (bank sampah dan shodaqoh sampah) menunjukkan bahwa terdapat partisipasi publik Indonesia yang cukup signifikan dalam pengelolaan sampah dan gagasan-gagasan pengelolaan sampah harus terus menerus muncul sehingga masyarakat akan tertarik untuk terlibat aktif sehingga gerakan pengelolaan sampah menjadi masif dan efektif - disampasing ketersediaan regulasi dan turunannya, infrastruktur, pemantauan dan evaluasi, serta enforcement juga tidak kalah penting sebagai penunjang kesuksesan program pengelolaan sampah.

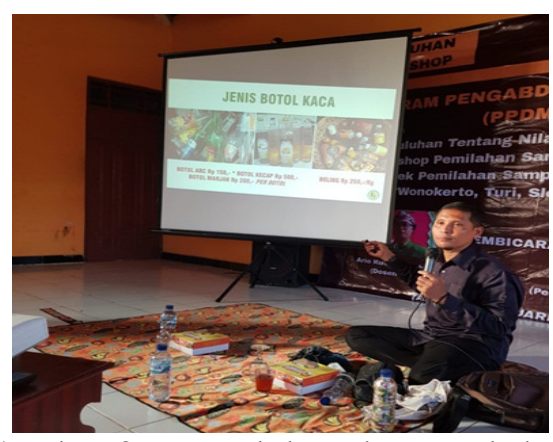

Gambar 2: Penyuluhan dan Workshop Pemilahan Sampah Kering Aula gedung pertemuan Pedukuhan Kembang, 19 Januari 2020 
Kemudian, bagian kedua merupakan Workshop dan Praktek Pemilahan Sampah Kering dengan pemateri Bapak Ananto Isworo, penggagas gerakan shadaqoh sampah di Kampung Brajan, Tamantirto, Bantul yang bersedia berbagi tentang kegiatan shadaqoh sampah dan gerakan eco masjid (Gambar 2). Menurut Bapak Ananto, pilihan menekuni gerakan shadaqoh sampah berdasarkan fakta bahwa lebih mendorong masyarakat untuk berbuat iklas demi sesama. Siapapun bisa bersedekah walaupun orang yang kurang mampu - tidak perlu menunggu penghasilan banyak baru bersedekah. Karena dengan hanya satu lembar kertas bekas (sampah) orang sudah bisa membantu sesama (bersedekah). Spirit ini yang mendorong warga di Kampung Brajan mendukung program sampah, baik muda maupun tua semua terlibat. Apalagi hasil dari penjualan digunakan untuk kegiatan sosial seperti memberi santunan kepada janda dan fakir miskin seperti memberi beasiswa bagi warga yang kurang mampu. Hingga akhirnya (karena kependulian masyarakat yang meningkat) masyarakat mulai memberikan shadaqoh dalam bentuk TV, kulkas, mobil dan lainlain karena tahu bahwa barang-barang tersebut akan digunakan dan dijual untuk membiayai kegiatan sosial. Bahkan pemberi shadaqoh pun berasal dari luar Kampung Brajan.
Hal ini berbeda dengan implementasi bank sampah yang secara umum mendorong masyarakat untuk menyetor sampah rumah tangga dan mencatat pemasukan untuk diri pribadi sehingga tiap nasabah akan berharap agar jumlah sampahnya banyak sehingga penghasilan besar. Bahkan pengurus bank sampah pun mendapatkan jatah penghasilan 10 persen dari penjualan sampah. Sementara dalam gerakan shadaqoh sampah semua berdasarkan kerja ikhlas demi membantu sesama sehingga para donatur, pengelola dan pengepul sampah lebih termotivasi. Selain memberikan materi, Pak Ananto juga melatih peserta dalam memillah sampah - misalnya, bagaimana memilah beberapa bagian botol sesuai dengan jenisnya masing masing (tutup dan cincin botol plastik) sehingga harga jualnya lebih tinggi dan bagaimana memanfaatkan pakaian bekas menjadi tas menarik, seperti yang ditunjukkan oleh Gambar 3.

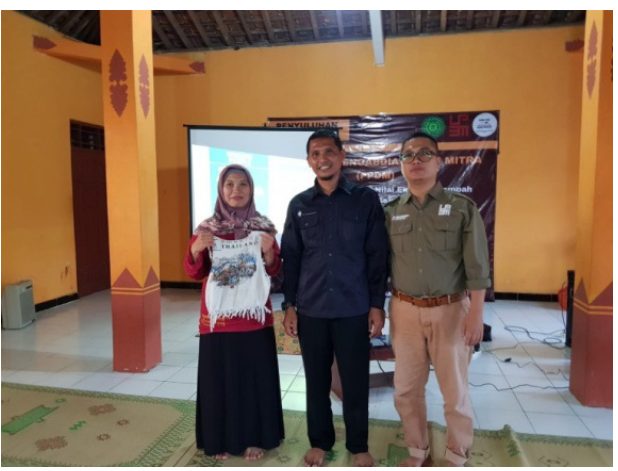

Gambar 3: Penyuluhan dan Workshop Pemilahan Sampah Kering

Aula gedung pertemuan Pedukuhan Kembang, 19 Januari 2020 


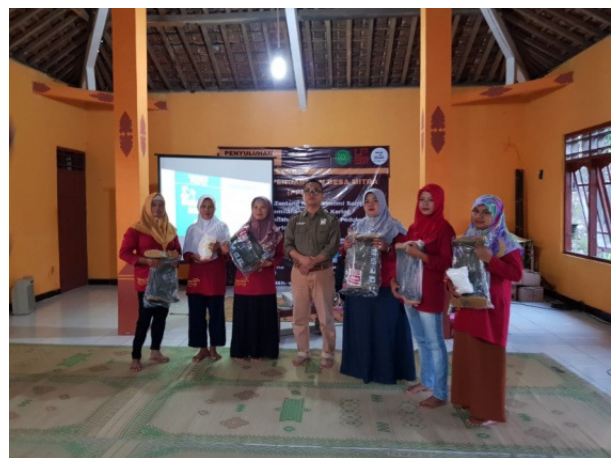

Gambar 4: Penyuluhan dan Workshop

Pemilahan Sampah Kering

Aula gedung pertemuan Pedukuhan Kembang, 19 Januari 2020

Tak lupa, setelah Kegiatan Workshop, Penyuluhan dan Praktek Pemilahan dan Daur Ulang Sampah, Tim Pengabdi memberikan hibah berupa sepatu boot, masker dan sarung tangan kepada para peserta yang hadir (Gambar 4).

Hal ini dilakukan guna mendukung pelaksanaan program pengelolaan sampah dimasing-masing pedukuhan sehingga bisa berjalan dengan baik.Salah satu responden misalnya mengatakan bahwa "Saya sangat bahagia sekali mendapatkan hibah dari UMY karena memang fasilitas yang dimiliki oleh kelompok pengelolaan sampah di Pedukuhan Kembang sangat terbatas sehingga barang-barang hibah yang diberikan sangat bermanfaat dalam menunjang kegiatan kami” (Responden 2).

Poin yang sama juga disampaikan oleh peserta dari pedukuhan lain (Respoden 3 dan 4). Hal ini menunjukkan bahwa disamping kegiatan workshop dan penyuluhan pengelolaan sampah menjadi wahana memberikan informasi dan pengalaman praktis bagi peserta, juga saling mendorong supaya programprogram yang ada bisa berjalan lebih baik. Gambar 5 menunjukkan dokumentasi peserta dan Tim Pengabdi UMY.

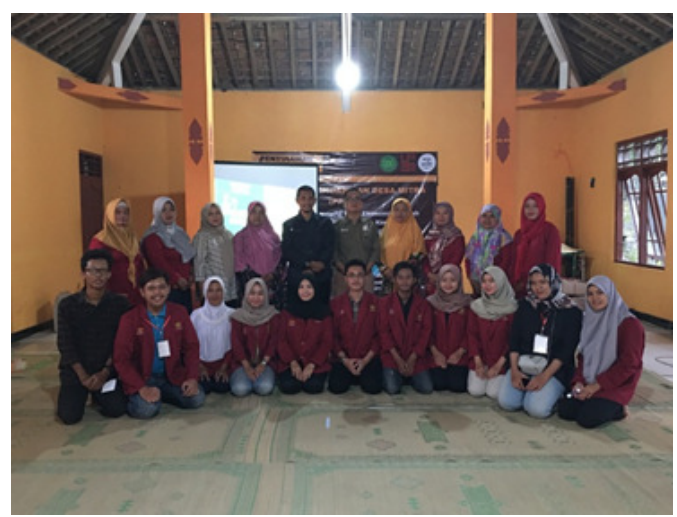

Gambar 5: Penyuluhan dan Workshop Pemilahan Sampah Kering

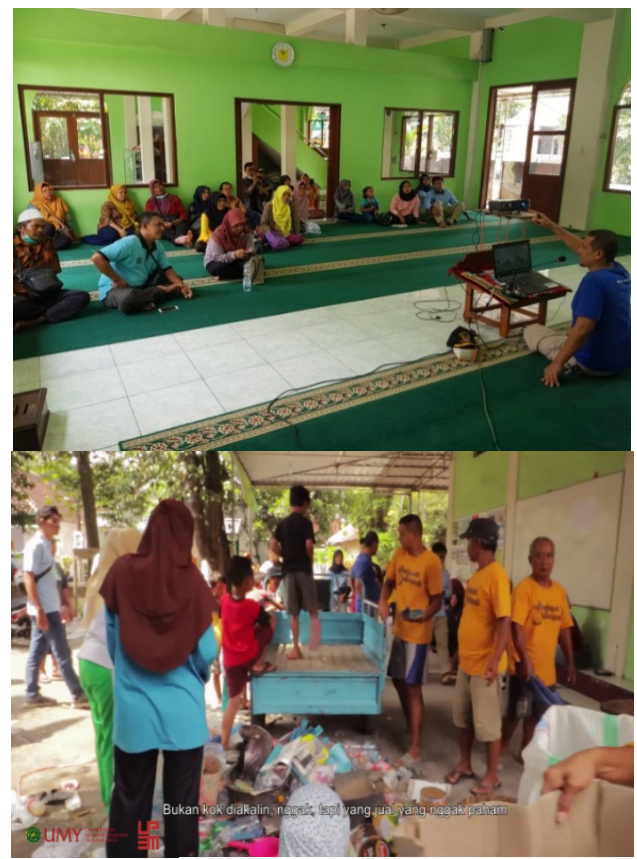

Gambar 6: Fieldtrip pengelolaan sampah dengan metode shodaqoh

Masjid Al-Muharram Kampung Brajan, 15 Maret 2020

Bagian paling akhir dari kegiatan tahap pertama ini, yaitu kunjungan lapangan (field trip) ke gerakan shadaqoh sampah di Kampung Brajan, Tamantirto, Kasihan, Bantul (Gambar 6).Sejak awal perencanaan Tim Pengabdi memang telah 
menjadwalkan untuk menjadikan gerakan shadaqoh sampah Kampung Brajan sebagai contoh inisiasi pengelolaan sampah tingkat masyarakat yang cukup berhasil dan dijadikan rujukan nasional dan internasional. Salah satu buktinya adalah Bapak Ananto Isworo (Pendiri Gerakan Shadaqoh Sampah kampung Brajan) diundang pada Global Forum on Environment - Mainstreaming Gender and Empowering Women for Environmental Sustainability yang diselenggarakan Organisation For Economic Cooperation and Developmentdi Paris, 5-6 Maret 2020 atau 10 hari sebelum kunjungan lapangan dilakukan.

Adapun dalam kegiatan tersebut Bapak Ananto diminta untuk menjelaskan kiat-kiat pengelolaan shadaqoh sampah dan dan gerakan Eco Masjid. Oleh karena itu, dengan melibatkan Pak Ananto (melalui penyampaian materi gerakan shadaqoh sampah) dan kunjungan pengelolaan sampah di Kampung Brajan dapat meningkatkan motivasi dan inspirasikelompok pengelola sampah di Pedukuhan Sembung dan Kembang sehingga program-program yang dijalankan dengan lebih efektif.

2. Monitoring pasca kegiatan pengabdian

Setelah pelaksanaan kegiatan tahap pertama, Tim Pengabdi mengagendakan monitoring dan evaluasi program pengabdian masyarakat (Gambar 7), khususnya untuk melihat bagaimana perkembangan kegiatan pengelolaan sampah dimasing-masing pedukuhan yang terlibat sebagai peserta program pengabdian.Berdasarkan wawancara dengan perwakilan pengurus gerakan pengelolaan sampah, maka ditemukan dua poin berikut.

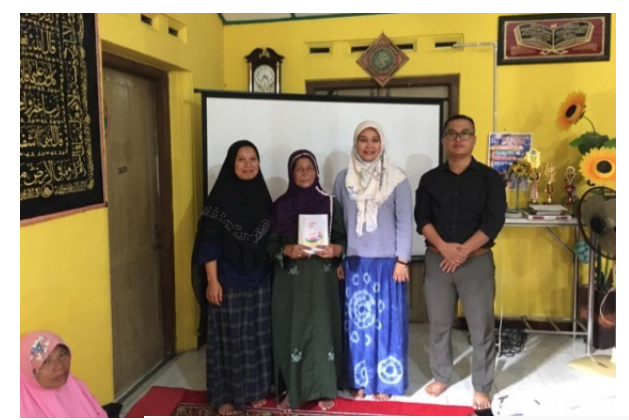

Gambar 7: Monitoring dan evaluasi program pengabdian

Rumah warga di Pedukuhan Kembang, 5 Februari 2020

Pertama, di Pedukuhan Kembang program pengelolaan sampah berubah dari bank sampah ke shodaqoh sampah (Responden 1, 2 dan 3). Hal ini diputuskan oleh para pengurus supaya tidak terbebani proses administrasi yang wajib dilakukan dalam pengelolaan bank sampah. Baik pengelola dan pengepul diingatkan bahwa kegiatan pengelolaan sampah melalui shadaqoh sampah yang baru saja diinisiasi bertujuan sosial, keagaaman dan demi kemaslahatan masyarakat sehingga baik semua yang terlibat akan mendapatkan pahala jika berkontribusi dengan baik. Namun, jika mereka melakukan berbagai hal yang mengganggu program (misalnya, pengurus melakukan penyimpangan keuangan atau pengepul yang telat membayar uang penjualan sampah) akan menambah dosa. Dampaknya adalah semua 
orang banyak terlibat aktif dalam dikelola dalam bank sampah demi pengelolaan sampah karena demi mendukung kegiatan sosial.

tercapainya tujuan shadaqoh sampah. Khusus yang di Pedukuhan Kembang, Apalagi mereka tahu hasil dari penjualan pengelola shadaqoh sampah adalah ibu-ibu sampah akan digunakan untuk mereka yang membutuhkan (beasiswa bagi yang putus sekolah, santunan bagi lansia dan untuk membiayai kegiatan sosial), berbeda dengan bank sampah pada umumnya yang mana uang hasil penjualan sampah akan kembali kepada pemilik sampah. Sehingga bagi yang memiliki sampah banyak akan mendapatkan uang paling banyak.

Dampak dari tujuan shadaqoh sampah yang lebih mengedepankan tujuan sosial keagamaan ketimbang keuntungan pribadi mendorong masyarakat untuk terlibat aktif dan bersedia menyumbangkan barangbarang bekas yang bernilai cukup tinggi. Seperti yang disampaikan oleh Responden 2 yang merupakan ketua kelompok shadaqoh sampah di Pedukuhan Kembang yang mengatakan: "Semua warga termasuk yang kaya bersedia menyumbangkan sampahnya dan kami jual dan laku seharga RP 500.000. Kemudian mereka bersedia menyumbangkan TV dan kulkas bekas yang laku dengan harga cukup mahal. Pengelola shadaqoh juga membuat kebijakan lain seperti: pemutihan (tidak perlu dibayar) kepada pengepul sampah yang belum menyelesaikan pembayaran pembelian sampah. Masyarakat juga diminta secara sukarela untuk menyedekahkan barang-barang yang telah majelis taklim. Adapun aktivitasnya dimotori oleh Ibu Dukuh yang semakin semangat sejak mengikuti penyuluhan dan workshop shadaqoh sampah pada bulan Januari 2020. Keterlibatan Bu Dukuh selaku perangkat desa dan ibu-ibu majelis taklim menjadi kunci kelancaran program shadaqoh sampah. Namun bedanya, jika di Kampung Brajan terletak diwilayah perkotaan dan terdiri dari masyarakat yang konsumtif sehingga sampahnya berjumlahnya banyak. Pedukuhan Kembang sebaliknya, terletak di pedesaan dan masyarakatnya tidak konsumtif sehingga jumlah sampahnya tidak terlalu banyak. Meskipun demikian, gerakan shadaqoh sampah, khususnya di Pedukuhan Kembang cukup aktif mempromosikan arti penting gerakan shadaqoh sampah dilingkup Desa Wonokerto sehingga program serupa dapat diadopsi oleh pedukuhan lain. Menurut hasil wawancara, bahkan $\mathrm{Bu}$ Dukuh mendapatkan kesempatan untuk mempresentasikan konsep shadaqoh sampah di Balai Desa Wonokerto dan mendapatkan apreasiasi dari peserta yang hadir. Hal ini menunjukkan bahwa program pengabdian yang dilakukan berjalan sesuai dengan harapan karena selain meningkatkan motivasi dan insiprasi 
bagi peserta kegiatan pengabdian juga mendorong kelompok tersebut untuk menyebarkan semangat yang mereka miliki dan menginsirasi kelompok lain untuk menginisiasi dan terlibat aktif dalam program shadqoh sampah di wilayahnya masing-masing.

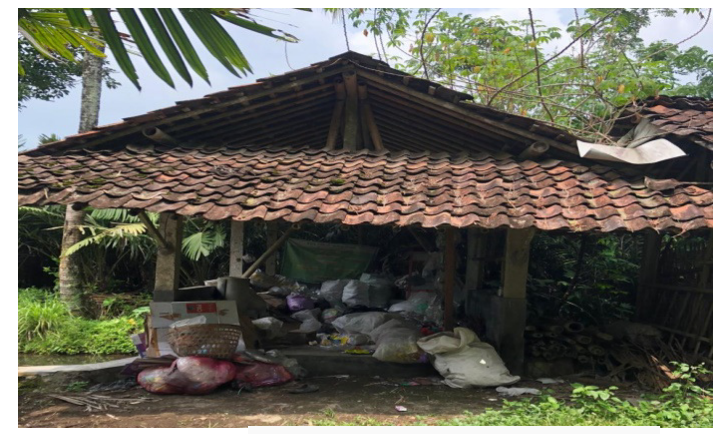

Gambar 8: Gudang shadaqoh sampah

Pedukuhan Kembang

Dokumentasi Tim Pengabdi, 5 Januari 2020

Informasi lebih lanjut yang diterima Tim Pengabdi dari Pak Dukuh (Responden 1) bahwa Pemerintah Pedukuhan Kembang telah mengajukan dana ke desa untuk membangun gudang khusus untuk program shadaqoh sampah dan telah disetujui. Adapun letaknya dibelakang kediaman Pak Dukuh - bentuk fisiknya sesuai dengan yang terlihat pada Gambar 8 diatas. Langkah kedepan, pengelola gerakan shadaqoh sampah Pedukuhan Kembang berencana untuk membangun etalase shadaqoh sampah di depan Gedung Pertemuan Pedukuhan Kembang untuk memamerkan hasil kegiatan kreatif masyarakat dalam mengolah sampah kreatif menjadi barang berharga dan bernilai ekonomi. Etalase juga akan memamerkan foto-foto kegiatan shodaqoh sampah yang dikelola masyarakat.

Hingga saat ini belum ada waktu permanen untuk kegiatan pemilahan dan penjualan sampah gerakan shadaqoh sampah Pedukuhan Kembang - berbeda dengan gerakan shadaqoh sampah di Kampung Brajan yang memiliki waktu permanen setiap minggu ke 2 dan ke 4 setiap bulan. Waktunya hanya diesuaikan dengan kegiatan majelis taklim yang diadakan sebulan sekali. Namun, secara umum kegiatannya berjalan dengan baik, meskipun hanya dikelola oleh 6 orang. Sama dengan gerakan sampah dipedukuhan lain, masih terdapat beberapa kendala klasik yang dihadapi pengurus yaitu kesadaran dan partisipasi masyarakat yang sangat terbatas. Namun pengelola tetap optimis sejalan dengan berjalan waktu kesadaran dan partisipasi masyarakat akan meningkat. Apalagi terdapat banyak manfaat positif yang didapat selama pelaksanaan program shadaqoh sampah, seperti yang diutarakan Kepala Dukuh Kembang: "Setelah adanya shadaqoh sampah masyarakat tidak lagi patungan sumbangan untuk bayar pengajian, cukup dengan menggunakan dana shadqoh sampah. Ini hasil kesepakatan masyarakat" (Respoden $1)$.

Berbeda dengan Pedukuhan Kembang, masyarakat di Pedukuhan Sembung sepakat tetap melanjutkan gerakan bank sampah yang sudah ada tetapi uang yang dikasilkan 
dikelola sama dengan shadaqoh sampah.

Artinya uang tidak dikembalikan kepada

individu (seperti yang system yang lazim digunakan dalam bank sampah) akan tetapi digunakan untuk kegiatan sosial kemasyarakatan dan keagaamaan dan hal ini disepakati oleh warga, utamanya yang terlibat dalam program bank sampah (Responden 7). Menurut Bapak Herjunanta, selaku Kepala Dukuh Sembung, dikarekanakan kegiatan pengabdian berada dalam situasi pandemi COVID-19 pelaksanaan pengelolaan sampah dilakukan secara mandiri oleh masyarakat dengan dikoordinir oleh para ketua rukun tetangga (RT). Jika situasi sudah membaik maka bank sampah yang telah ada di Dukuh Sembung akan diaktifkan kembali, dengan model pengelolaan shodaqoh sampah. Namun tentu saja, pengelolaannya akan tetap mengacu pada Peraturan Menteri Negara Lingkungan Hidup No 13 Tahun 2012 tentang Pedoman Pelaksanaan 3R (Reduce, Reuse, dan Recycle).

Seperti yang terjadi di Pedukuhan Kembang, terdapat beberapa kendala yang dihadapi oleh pengelola bank sampah di Pedukuhan Sembung. Pertama, Dukuh Sembung kekurangan sumber daya manusia yang bersedia terlibat aktif dalam pengelolaan sampah. Para relawan yang ada sekarang pun masih memerlukan peningkatan pemahaman dan motivasi mengenai pentingnya pengelolaan sampah dengan metode bank sampah dan shodaqoh sampah sehingga memerlukan pendampingan terus menerus. Kendala yang terakhir adalah pentingnya dukungan dana untuk memperbaiki gudang yang sudah ada dan meningkatkan kapasitas daya tampungnya. Tiga kendala ini menjadi kunci keberlangsungan program pengelolaan sampah di Pedukuhan Sembung.

\section{KESIMPULAN}

Berdasarkan penjelasan diatas maka dapat disimpulkan bahwa program pengabdian masyarakat yang dikelola oleh Tim Pengabdi UMY telah berkontribusi dalam menguatkan gerakan pengelolaan sampah di Pedukuhan Kembang dan Sembung yang masing-masing berlokasi di Desa Wonokerto dan Purwobinangun, Kabupaten Sleman. Hal ini ditunjukkan dari meningkatnya motivasi dan peran aktif kelompok gerakan sampah yang terlibat program pengabdian. Peran aktif bukan hanya dalam mengelola gerakan sampah dalam lingkung internal pedukuhan saja, akan tetapi mampu menjadi agen yang menyebarkan tentang pentingnya pengelolaan sampah dengan spirit shadaqoh sampah demi tujuan sosial kemasyarakatan dan keagaaman. Paradigma seperti ini mendorong semua stakeholder yang terlibat dalam pengelolaan sampah menjadi terlibat aktif.

Padahal sebelumnya, ketika program pengabdian belum dilaksanakan, gerakan pengelolaan sampah berjalan, seperti di Pedukuhan Kembang dan Sembung vakum. 
Ini berarti gerakan pengelolaan sampah tidak cukup hanya fokus pada bagaimana memilih dan menjual sampah sehingga mendapatkan keuntungan (meskipun dengan menggunakan nama bank sampah maupun shadaqoh sampah). Perlu penekanan pada spirit tujuan sosial keagaamaan, bukan semata-mata demi kepentingan pribadi. Faktor ini akan semakin mendorong banyak pihak untuk terlibat aktif, seperti yang telah dicontohkan pada kegiatan pengabdian penguatan gerakan pengelolaan sampah di Pedukuhan Kembang, dan Sembung.

\section{UCAPAN TERIMA KASIH}

Tim pengabdi ingin mengucapkan terimakasih yang sebenar-besarnya kepada Lembaga Penelitian, Publikasi dan Pengabdian Masyarakat Universitas Muhammadiyah Yogyakarta yang telah memberi Hibah Pengabdian Pengabdian dengan nomer kontrak 031/PENLP3M/I/2020 sehingga Tim Pengabdi dapat melaksanakan program dan menulis draft publikasi. Ucapan terimakasih juga diberikan kepada Kepala Desa Wonokerto dan Purwobinangun atas segala dukungan yang diberikan selama persiapan dan pelaksanaan program. Dan yang paling penting, Tim Pengabdi mengucapkan terimakasih kepada Kepala Dukuh Kembang dan Sembung, para pengelola gerakan sampah dan masyarakat yang mendukung dan terlibat aktif selama kegiatan.

\section{REFERENSI}

[1] Badan Pusat Statistik. (2017). Data Jumlah Penduduk Propinsi Daerah Istimewa Yogyakarta. Jakarta.

[2] Dinas Lingkungan Hidup Kabupaten Sleman. (2017). Data pengelolaan sampah di Kabupaten Sleman. Sleman: Dinas Lingkungan Hidup Kabupaten Sleman.

[3] Suryana, W. (2019). Sleman tambah lagi bank sampah. Republika. Retrieved from https://nasional.republika.co.id/berita/psi p9v370/sleman-tambah-lagi-banksampah

[4] Nasrudin. (2019). Resmikan bank sampah, warga Sleman ajak lebih peduli mengelola sampah. ACT News. Retrieved from https://news.act.id/berita/resmikan-banksampah-warga-sleman-ajak-lebih-pedulimengelola-sampah

[5] Peraturan Menteri Lingkungan Hidup Nomor 13 tahun 2012

[6] Burhan, F. A. (2018). Kabupaten Sleman Miliki 178 Bank Sampah. Harian Jogja. Retrieved from https://jogjapolitan.harianjogja.com/read /2018/12/06/512/957236/kabupatensleman-miliki-178-bank-sampah

[7] Panji Nasional. (2020). Peringatan hari sampah, pemerintah diminta seriusi bank sampah. Panji Nasional. Retrieved from https://panjinasional.net/2020/03/01/peri ngatan-hari-sampah-pemerintah-dimintaseriusi-bank-sampah/

[8] Rusqiyati, E. A. (2017). Bank sampah tidak aktif jadi sasaran pembinaan.Antara News. Retrieved from https://jogja.antaranews.com/berita/3512 21/bank-sampah-tidak-aktif-jadisasaran-pembinaan

[9] Putra, H. P., Damanhuri, E., \& Sembiring, E. (2019). Sektor baru pengelolaan sampah di Indonesia (studi kasus di Kota Yogyakarta, Kabupaten Sleman dan Bantul). Jurnal Sains dan Teknologi Lingkungan, 11(1), 11-24. doi:10.20885/jstl.vol11.iss1.art2 